\title{
The Legal System for the Administrative Supply Contract
}

\author{
Dr. Noor Issa Al-Hendi \\ Assistant Professor / College of Law / Applied Science Private University/ Jordan
}

\begin{abstract}
The public administration shall resort to concluding an administrative supply contract in order to ensure the regular functioning of public facilities and steadily in the state, given the need of all public utilities for movables, and the administration shall paid a price specified in the contract.however, the administration enjoys, under this contract, privileges and powers that make it a stronger legal position than the supplier, since it aims to achieve the public interest, so a balance must be found between the administration's interest in achieving the public interest and the interest of the resource that aims primarily to achieve profit as a result of concluding This contract, and it must be noted that there is judicial control exercised over all the administration's actions in order not to be arbitrary in the use of its privileges.
\end{abstract}

Keywords: administrative supply contract, supplier, administration, Jordanian supplies system, administration privileges.

DOI: $10.7176 / \mathrm{JLPG} / 98-23$

Publication date:June 30th 2020

\section{Introduction}

The administrative supply contract is one of the named administrative contracts, and it has practical significance so the administration resorted to concluding this contract to ensure the regular functioning of public facilities, by providing the administration with movable funds necessary to achieve the public interest, so this contract is a legal agreement, arranging certain legal effects towards the administration and others, and the administration applied the rules of administrative law, and until the contract is described in the administrative contract, certain conditions must be met, namely that one of the parties to the supply contract be a person of public law, and that the contract relates to a public utility activity, and that it is subject to the provisions of common law by including exceptional conditions unfamiliar to the private law .

This research will deal with the legal organization of the administrative supply contract by clarifying the concept of the administrative supply contract, its characteristics, the legal rules that govern it, and the conditions that must be met in it, as well as clarifying the methods for selecting the contractor with the administration in the administrative supply contract, and the restrictions on the administration's freedom to choose the contractor with it, and finally the implications of the administrative supply contract represented by the contractor's rights and obligations and management rights, then the conclusion of the research, recommendations and references.

\section{What is an administrative supply contract?}

2.1. Definition of the administrative supply contract

The Jordanian legislator In the Supplies Law No. (32) for the year 1993, did not define the contract of administrative contract, because this is a matter for jurisprudence and the judiciary, and by clarifying the Jordanian judicial; We find that it also did not define the contract of administrative supply, and the Jordanian High Court of Justice (Administrative Court) ruled that "the jurisprudence and jurisprudence consensus has taken place that the dispute regarding the contract or its validity is a human rights dispute that is considered by ordinary courts. ${ }^{1}$ "

Administrative supply contracts are organised by the Supplies Act No. (32) for the year 1993 if the subject of the contract relates to the supply of supplies. Also, they are subject to the Governmental Works act No. (71) for the year 1976 if they are related to public works, and the contracting procedures for supply contracts are regulated in accordance with the instructions for organizing tenders the conditions for participation in it No. 1 of 2008.

As for the jurisprudence, the administrative supply contract was defined as an agreement between a legal person of the public law "administration" with an individual or company "a contractor or supplier". The supplier undertakes under this agreement to supply the administration with certain movables necessary to run the public facility and ensure that it runs regularly and steadily, In exchange for a specific price specified in the contract, the materials and supplies agreed upon in the administrative supply contract are supplied in one payment, and may also be supplied over a long period of time $e^{2}$. The situation prevailing in supply contracts is that the administration is the importer, but the administration may be the supplier ${ }^{3}$.

The administrative supply contract is distinguished by responding to movables ${ }^{4}$; That is, the location of the

\footnotetext{
${ }^{1}$.Decision of the Jordanian High Court of Justice No. 40/1979 dated 3/3/1980 Adalah Publications

2 . Nawaf Kanaan, Administrative Law, Second Book, Dar Al-Thaqafa, Amman, 2009, p. 325

3. Mohammad Dhnibat, Al-Wajeez in Administrative Law, Dar Al-Thaqafa, Amman, 2016, p. 259.

${ }^{4}$.Mohammad Al-Khalayleh, Mediator in Administrative Law, Dar Al-Thaqafa, Amman, 2018, p. 358.
} 
contract is always movable material, and this is what distinguishes it from the administrative public works contract, which is only returned to real estate, It is necessary to refer to the second article of the Jordanian Supplies act where it stated that the supplies are "the movable funds necessary for any department and its maintenance, insurance and services needed by the department". So this article indicated that the subject of the contract is always movables. And the administrative supply contract is also distinguished as a consensual contract, which distinguishes it from the temporary seizure that the administration may resort to without the consent of the owner of the movables, but according to an administrative decision issued by the sole will of the administration, and implementation may be forced ${ }^{1}$, in this regard, the Jordanian High Court of Justice (Administrative Court) ruled that "Article two of the Public defense act No. two for the year 1939 issued pursuant to article Four of the defense Law has authorized the Prime Minister to secure public safety to order the seizure and disposal of any funds, and the owner of these The money is entitled to compensation ."

With regard to the conditions that must be met in the administrative supply contract; one of the parties to the contract must be a common law person; whether it is a central body or a decentralized or regional decentralized body $^{3}$, and the contract must also relate to a public utility activity; that is, for the contract to be considered administrative, its subject must be related to a public facility ${ }^{4}$, so Jordanian Supreme Court of Justice (Administrative Court) defined the public utility as "a collective need that reached an amount of importance that requires government intervention in order to provide it to individuals using the means of public law, whether individuals can by their own means satisfy that need or not, that is, the main element in the public attachment It is the necessity of having a service that the legislator aims to manage from the government directly or through a committed under its supervision, there is no difference between that service being related to commercial or industrial activities or otherwise...". 5

The administration must also follow the general law method of contracting, that is, the contract includes exceptional unusual conditions in the relations of individuals, and these conditions make the administration appear as a commanding and final party in the contract. In consideration, as well as the administration's authority to impose sanctions on its contractor ${ }^{6}$.

\subsection{Selecting the contractor "supplier or contractor" with the administration in the Jordanian supply contract}

There are certain principles that must be taken into consideration by the administration when choosing a contractor with it, stipulated in article nine of the Jordanian supplies act, so the administration must observe "the principle of competition in all supplies procurement whenever possible and in the manner that the procurement authority considers", and article (9/7) also stipulated that "procurement processes should take into account the best quality supplies at the best prices and conditions". With regard to restrictions on the administration's freedom to choose its contractor; Article (16/e) of the Jordanian Supplies act stipulates that "taking into account what is stated in this act any supplies worth more than twenty thousand dinars are purchased only by a bid committee formed in accordance with the provisions of the act". According to this legal text, the authority to select the contractor the jurisdiction of the Bidding Committee. According to Articles (17, 19 and 20), there are three committees concerned in this matter: the Central Bidding Committee, the Local Bidding Committee and the Special Bidding Committee.

for the methods of selecting the contractor with the administration; article (23) of the Supplies act stipulates that "bidding procedures, conditions for participation in them, the method of studying offers, referrals, and guarantees to be presented by competitors and contractors, and the responsibilities and obligations incurred by them when non-compliance with their offers or the implementation of referral contracts concluded with them, are organized according to instructions issued by the Minister and published in the Official Gazette. It is attached to every call made by any department". And article (15) of the Supplies act stipulates that "Procurement of supplies is carried out by bidding, that supplies may be purchased through solicitation of offers or by direct purchase in negotiation with their seller, product or supplier". Accordingly, there are two methods for selecting the contractor with the administration in the administrative supply contract, which are: buying through tenders, and buying through non-bids through inviting offers and direct purchase.

Article (15) of the Supplies act indicated that it is the original principle to purchase supplies to be by way of bidding, and with regard to the procedures for bidding and the prospects for participation in it, Article (23) of the Supplies act referred to instructions that regulate it. And Bidding procedures includes announcing the administration's intention to contract, submit offers, open offers and bid.

As for the announcement of the $\mathrm{bid}^{7}$, article (7) of the supplies act instructions stipulated the manner of its

\footnotetext{
1 .Hamdi Al-Kabilat, Administrative Law, Part Two, Second Edition, Dar Wael, Amman, 2016, p. 110.

2 . Resolution No. 57/1973 was dismissed on 1/1/1973 an ordinary organization published on page 1208 of issue 4 of the Journal of the Jordanian Bar Association for the year 1973.

3 . Mohammad Al-Khalayleh, Mediator in Administrative Law, p. 355.

4 . Hamdi Al-Kabilat, Administrative Law, P. 100.

. Decision of the High Court of Justice on 4/30/1969 Lawyers Syndicate Journal for the year 1969, p. 321.

. Hamdi Al-Kabilat, Administrative Law, p. 101

. Abdel-Hakim Othman, Supply Contract, University House of Thought, Alexandria, 2007, p. 46.
} 
announcement, stating that "the general manager or the general secretary shall announce the bidding with annual serial numbers of no less than three local newspapers in more than a day and by other means of advertising that he deems appropriate, and includes the announcement of The tender is an indication of the tender number, type of supplies, the deadline for selling the tender invitation, the deadline for submitting the tender, the price of the tender invitation, and any matters the general manager or general secretary deems necessary to announce. For an appropriate period of time if the student is seriously convinced and announces that with the same means of advertisement through which the tender was previously announced, and the Director General or the SecretaryGeneral announces the tender that has been decided to re-bid ${ }^{1 "}$

As for submitting offers ${ }^{2}$; article (18) of the instructions for organizing bids and conditions for participation in them specify the mechanisms for purchasing, preparing and submitting offers by bidders and the documents that bidders must attach to the tender invitation. The offers are opened by the Bidding Committee in full quorum or by a majority of its members in public in a specific place, date and hour in the announcement of the bid, and each bidder or his representative may attend the opening of the offers, then the bid opening record is organized in which the names of the bidders participating in the bid are registered with serial numbers and signed by the committee After opening all the offers, after that the offers submitted for the tender are studied according to their sequence in the price as stated in Article (47) of the instructions, and Article (52) of the instructions also specifies the method of assigning bids to winners according to specific grounds.

As for the purchase without bidding; They are solicitations and direct purchases ${ }^{3}$, they are subject to the instructions for purchasing supplies without bidding No. (1) for the year 1995 issued under Article (69) of the Jordanian Supplies act, In relation to purchasing by soliciting bids, Article (15 / A) of the Supplies act specifies the purchase of supplies in a way to solicit offers in specific cases exclusively, Article (15/d) of the same law also specifies cases of direct purchase by way of inventory Among the most important previous restrictions on the conclusion of the administrative supply contract the financial permission, because this contract requires expenditures incurred by the administration, so it must have a financial appropriation to meet the administration's obligations towards the supplier and this accreditation is originally allocated in the General Budget Law, this law determines the aspects of revenue And spending in advance ${ }^{4}$. If the administration refuses to pay on the pretext that the financial provision is not available, its contractual responsibility will be due to the breach of its contractual obligation $^{5}$.

\section{The effects of the administrative supply contract}

3.1. Supplier's obligations in the administrative supply contract

The supplier's obligations to fulfill his contractual obligations are represented in the specified period of implementation stipulated in the contract, and that the supply be made in accordance with the specifications agreed upon in the contract to ensure that the public facility runs regularly and that is what we will explain successively.

Commitment to supply movables on the agreed dates specified in the contract: in order to meet the need of the public facility and ensure that it runs regularly, and article (66) of the Jordanian Tender Regulation Instructions No. (1) of 2008 stipulated that "if the contractor fails to implement his obligations under the contract, or is short of that, or delays in Providing the supplies referred to it; the Bidding Committee in this case purchasing the supplies or services subject of the contract with the same specifications and characteristics, or a substitute for them with the same characteristics and uses, and not less than them together from any other source at his expense, and bearing price differences and additional expenses and any loss, expenses, breakdown, or damage to In the beneficiary department, or the General Supplies Department without the need for any warning, and the contractor has no right to object to that".

The supplier's commitment to supply the movables in accordance with the specifications agreed in the contract: the Jordanian legislator required that the supply be carried out according to the agreed specifications and the receiving process in a precise manner to ensure that the administration fulfills the supplier's implementation of its obligations. The bidding instructions instructions No. (1) of 1994 required the tenderer to submit well-executed insurance in the form of a bank guarantee or a certified check issued by a licensed bank, or financial institution. Likewise, the tenderer was obliged to provide implementation insurance within ten days of the referral notification, otherwise the matter is brought before the Bid Committee ${ }^{6}$.

\footnotetext{
. Mahmoud Al-Jubouri, Administrative Contracts, Dar Al-Thaqafa, Amman, 2010, p. 45.

. Hani Ismail, The Legal System of the Supply Contract, A Comparative Study, New University House, Alexandria, 2011 , p. 34.

Hamdi Al-Qabilat, Electronic Public Administration Legislation, Dar Wael, Amman, 2018, p 66.

4 . Mohamed Abdel-Fattah, Al-Shamil in Administrative Contracts at the Supreme Administrative Court until 2008, National Center for Legal Issues, 2009, Cairo, p. 354

5 . Khaled Al-Anzi, Arbitration in Administrative Contracts, a Comparative Study, Arab Renaissance House, Cairo, 2007, p. 185.

${ }^{6}$. Article 10 and Article 11 of the instructions for organizing bids and conditions for participation in them
} 


\subsection{Supplier's rights in the administrative supply contract}

The supplier in the administrative supply contract has the right to achieve a profit, and the right to ensure the financial balance of the contract ${ }^{1}$, because he personally committed to implementing contract, and fulfilling his obligations in the agreed times, so the supplier has the right to obtain the price in return for providing the department with movables, and he has the right for the administration to respect its contractual obligations, and then to receive compensation if the administration does not implement its contractual obligations in a way that is attached to it Harmful, as the jurisprudence and the judiciary recognized the supplier's right to ensure the financial balance of the contract, that his financial dues are balanced with the burdens and expenses incurred by him, and in the event of a defect in this balance, he is entitled to obtain management assistance, to restore the financial balance of the contract so that he can continue to implement his obligations ${ }^{2}$.

\subsection{Management Rights ${ }^{3}$}

The administration has broad powers towards the supplier because it is responsible for the public utility and for the public interest ${ }^{4}$, these privileges are enjoyed by the administration, whether stipulated in the contract or not provided for, because they are related to the public interest, and the failure to stipulate or neglect it does not mean depriving the administration of its exercise, and these privileges are what gave the contract the description of the administrative contract ${ }^{5}$, these privileges are: The administration's authority to control, direct and supervise the resource $^{6}$, the administration's authority to amend the administrative supply contract ${ }^{7}$, and the authority of the administration to impose sanctions on the supplier ${ }^{8}$.

The authority of the administration to control, direct and supervise the supplier: that is, the administration monitors the supplier's implementation of the obligations stipulated in the administrative supply contract, to ensure that the contract is implemented in accordance with the conditions set forth in it, so in order to achieve the public interest the administration exercises its authority to control and direct the supplier 9

The authority of the administration to amend the administrative supply contract: Article (28) of the french decree issued on the 11th of Masso in 1953 recognized this right for the administration in the administrative supply contract, as it stipulated that "if what happened during the implementation, the volume of works or supply has been amended by order of interest, and in a way that challenges The limits mentioned in the contract ... ", as well as Article (20) of the Public Procurement Law No. (75) of 2006 stipulating that" in the event of unforeseen difficulties arising out of, and not due to, the act of the parties to the contract or because of them, in this case an attachment or follow-up decision is required. "For the contract, without looking at the financial value of the adjustment resulting from these variables, and in all cases the status of the contract attachment must not overturn the contract economics, nor should it change the subject of the contract in its place ${ }^{10 "}$.

Finally, the administration's authority to impose sanctions on the supplier: A penalty may not be imposed by the administration on the supplier unless he committed a mistake and violated his contractual obligations, such as his lack of commitment to implement the contract personally or his failure to respect the implementation period agreed upon in the contract ${ }^{11}$

\section{Conclusion}

The administrative supply contract is defined as an agreement between the administration and a contractor or supplier, whereby the contractor undertakes to supply the department with necessary movables to ensure the general facility runs regularly and steadily, against a price specified in the contract and supplies agreed to in the supply contract may be supplied in one payment as it may be supplied over Long time period.

Administrative supply contracts are distinguished by being returned to movables and consensual contracts, and are also subject to the Supplies Law No. (32) for the year 1993 if the location of the contract relates to the supply of supplies, and they are also subject to the government works system No. (71) for the year 1976 if the contracts are related to public works, The contracting procedures for supply contracts are regulated in accordance with the instructions for organizing tenders and conditions for participation in them No. (1) for the year 2008.

One of the parties to the contract must be a common law person; The contract must relate to a public utility activity, and the administration should follow the common law method of contracting by including the

\footnotetext{
. Mohamed Abdel-Wahab, Administrative Law, New University House, Alexandria, 2010, p. 37.

Suleiman al-Tamawi, General Principles in Administrative Contracts, p. 564.

.hamad Al-Shalmani, Privileges of the Public Authority in the Administrative Contract, University Press, Cairo, 2007, p. 100.

. Mohammad Thunaibat, Al-Wajeez in Administrative Law, p. 266.

. Ali Shatnawi, Jordanian Administrative Law, Book Two, Dar Wael, Amman, 2009, p. 714

. Suleiman al-Tamawi, General Principles in Administrative Contracts, Cairo, 1984, p. 548.

supreme Court of Justice Decision No. 436/94 / No. 7 of 1995, p. 1843.

Supreme Court of Justice Decision No. 42/86/7 7 of 1987 p. 1477.

. Suleiman al-Tamawi, General Principles in Administrative Contracts, p. 548.

10. Hani Ismail, The Legal System of the Supply Contract, p. 843.

1 . Ibrahim Al-Fayadh, Administrative Contracts, Al-Falah Library, 1981, p. 122.
} 
contract with unusual conditions in the relationships of individuals.

When selecting the supplier or the contractor in the supply contract, the principle of competition must be taken into account in all procurement of supplies, and to obtain the best supplies at the best prices and conditions. There is a restriction on the administration's freedom to choose the supplier, as any supplies worth more than twenty thousand dinars are purchased only by a bid committee.

Bid procedures, conditions for participation in them, method of studying offers, assignment, and guarantees to be presented by competitors, contractors, responsibilities and obligations incurred by them in non-compliance with their offers or implementation of referral contracts concluded with them are organized according to instructions issued by the minister and published in the Official Gazette and attached to every invitation raised by any department. Purchase of supplies by tender. It is permissible to purchase supplies by inviting offers or through direct purchase by negotiating with their seller, producer or supplier.

One of the most important previous restrictions on the conclusion of the administrative supply contract is the financial permission, because the supply contract requires expenditures, so it must have financial support to meet the administration's obligations to the supplier.

The supplier's obligations are in the administrative supply contract by committing to supply the movables at the agreed times specified in the contract, and to provide the administration with the movables according to the specifications agreed in the contract, while the supplier's rights are to make a profit, and ensure the financial balance of the contract. The administration's prerogatives in its authority are oversight, direction, supervision, amending the supply contract, and the imposition of sanctions.

\section{Recommendations}

1. Unify the rules related to the administrative supply contracts mentioned in the Jordanian supplies system and the government works system in order to make it easier for stakeholders to familiarize themselves with them.

2. Specify an administrative body competent to conclude the administrative supply contract instead of the large number of committees. Therefore, it is necessary to settle for forming a central bidding committee.

3. That there be limited bids in which participation is limited to suppliers whose names are approved in lists determined by the competent authority.

\section{References and Resources}

Books:

Al-Fayadh. I. (1981), Administrative Contracts, Al-Falah Library.

Al-Khalayleh. M. (2018), Mediator in Administrative Law, House of Culture, Amman.

Al-Kabilat. H. (2016), Administrative Law, Part Two, Second Edition, Dar Wael, Amman.

Al-Anzi. K. (2007), Arbitration in Administrative Contracts, A Comparative Study, Arab Renaissance

House, Cairo.

Abdel-Fattah. M. (2009), Comprehensive in Administrative Contracts at the Supreme Administrative

Court until 2008, National Center for Legal Issues, Cairo.

Al-Tamawi. S. (1984), General Bases of Administrative Contracts, Cairo.

Al-Jubouri. M. (2010), Administrative Contracts, House of Culture, Amman.

Al-Shalmani. H. (2007), Privileges of the Public Authority in the Administrative Contract, University Press, Cairo.

Abdel-Wahab. M. (2010), Administrative Law, New University House, Alexandria.

Al-Kabilat. H. (2018), Electronic Public Administration Legislation, Dar Wael, Amman.

Dhnibat. M. (2016), Al-Wajeez in Administrative Law, Dar Al-Thaqafa, Amman.

Kanaan. N. (2009), Administrative Law, Second Book, Dar Al-Thaqafa, Amman.

Ismail. H. (2011), The Legal System of the Supply Contract, A Comparative Study, New University

House, Alexandria.

Othman. A. (2007), Supply Contract, University House of Thought, Alexandria.

Shatnawi. A. (2009), Jordanian Administrative Law, Second Book, Wael House, Amman.

Law:

Jordanian Supplies act No. (32) of 1993.

Jordanian Public Works Regulation No. (71) of 1976.

\section{Instructions:}

Tender Regulations and Participation Conditions No. (1) of 2008

Instructions for purchasing supplies other than through Jordanian Tenders No. (1) of 1995. 